\title{
GRAMATYKA Z KULTURĄ - O WSPÓŁCZESNYCH ŚCIEŻKACH NAUCZANIA GRAMATYKI
}

Słowa kluczowe: glottodydaktyka, gramatyka, fleksja, kultura

Streszczenie. Przy rozwijaniu kompetencji gramatycznej główny nacisk jest położony na pragmatykę językową (skuteczność komunikacji), a znajomość gramatyki jest traktowana jako środek budowania wypowiedzi, które służą realizowaniu poszczególnych intencji nadawczych. Widoczna staje się tu również dbałość o atrakcyjność zadań oraz łączenie zagadnień gramatycznych z przekazywaniem wiedzy o polskiej kulturze, co stanowi temat niniejszego artykułu. Wyrażenie: „gramatyka z kulturą" poprzez swoją wieloznaczność pozwala scharakteryzować współczesne sposoby kształtowania kompetencji gramatycznej w nauczaniu języka polskiego jako obcego. „Z kulturą" znaczy tu: kulturalnie (atrakcyjnie, przejrzyście), z nauczaniem zasad etykiety oraz z elementami wiedzy o polskiej kulturze.

Miejsce gramatyki w nauczaniu języków obcych podlega zmianom, co wynika z dwóch zasadniczych względów. Po pierwsze, na przestrzeni lat pojawiają się różne podejścia do nauczania języka (w tym i gramatyki) ${ }^{1}$. Po drugie, programy dydaktyczne są dostosowywane do potrzeb poszczególnych odbiorców (np. przy pracy w grupach wschodniosłowiańskich znacznie większy nacisk zostaje położony

*bartlomiej.maliszewski@mail.umcs.pl, Uniwersytet Marii Curie-Skłodowskiej, Centrum Języka i Kultury Polskiej, ul. Weteranów 18, 20-038 Lublin.

${ }^{1}$ Przy metodzie audiolingwalnej nacisk zostaje położony na automatyzm zachowań językowych, więc pomijaniu podlega refleksja nad zasadami budowania wypowiedzi. Przy podejściu kognitywnym, które jest rozwinięciem metody gramatyczno-tłumaczeniowej, dużo uwagi poświęca się zaś rozumieniu i przyswajaniu reguł językowych. Przy dominujących dziś podejściach (komunikacyjnym oraz zadaniowym) gramatyka jest traktowana jako środek sprawnego posługiwania się językiem, realizowania różnorodnych intencji nadawczych i budowania fortunnych aktów mowy - zob. Komorowska 1993, s. 21-25, 117, Seretny, Lipińska 2005, s. 111-112, Izdebska-Długosz 2016, Jasińska 2016, s. 67-68, Gębal, Miodunka 2020, s. 228-241. 
na rozwój kompetencji gramatycznej i często są wykorzystywane ćwiczenia, których celem jest zwalczanie interferencji zjęzyka ukraińskiego lub rosyjskiego) ${ }^{2}$.

Nie ulega jednak wątpliwości, że warunkiem sprawnej komunikacji jest płynność, zrozumiałość oraz poprawność (tworzonych i odbieranych) wypowiedzi:

Jeśli obcokrajowiec powie: „trzecia - ja - przyjść - pan tu - ta biuro” to skuteczność jego wypowiedzi będzie bardzo duża i informacja zostanie przekazana. (...) Wiadomo jednak, że niekiedy znajomość gramatyki zaburza komunikację, powodując nieporozumienia, a poza przekazaniem informacji - w porozumiewaniu się istotna jest także pewna elegancja przekazu.

(Komorowska 1993, s. 164)

Nie można (...) ograniczać nauczania języka do rozwijania umiejętności skutecznego zdobywania i przekazywania informacji. Trzeba także dbać o to, by przekaz był poprawny i zrozumiały.

(Seretny, Lipińska 2005, s. 112)

Wskaźnikiem dużego zainteresowania gramatyką oraz jej istotnego znaczenia jest wielość materiałów poświęconych tej dziedzinie ${ }^{3}$. Rozbudowany jest tu dział językoznawczy (o gramatyce), metodyczny (o nauczaniu gramatyki) oraz dydaktyczny (materiały do nauczania i testowania gramatyki). Publikowane podręczniki czy zbiory zadań są nie tylko źródłem pomocy do nauczania języka polskiego, ale też dostarczają wzorców oraz inspiracji do tworzenia kolejnych ćwiczeń.

Poszukując wyrażeń, które pozwoliłyby zwięźle scharakteryzować współczesne ścieżki nauczania gramatyki w nauczaniu języka polskiego jako obcego, można podać trzy główne hasła, które wzajemnie się dopełniają.

Pierwszym hasłem jest wyrażenie gramatyka w praktyce - nacisk jest bowiem położony na komunikację, rozwijanie sprawności językowych (słuchania, czytania, mówienia, pisania), a gramatyka stanowi przedmiot uwagi jako środek realizowania poszczególnych intencji komunikacyjnych, np. znajomość trybu rozkazującego pozwala formułować nieoficjalne zaproszenia, prośby, rady itp. (zob. Komorowska 1993, s. 173-174)4.

${ }^{2}$ Specyfika nauczania studentów ze Wschodu (w tym osób z polskim pochodzeniem) stanowi temat bogatej literatury glottodydaktycznej, czego przykładem jest m.in. cykl publikacji wydanych w serii Kształcenie Polaków ze Wschodu (red. Mazur 1992, 1993, 1994, 1995, 1996) oraz poradniki metodyczne przeznaczone dla nauczycieli języka polskiego jako obcego na Wschodzie - Dąbrowska, Dobesz, Pasieka 2010, Foland-Kugler 2001, Kowalewski 2013, Krawczuk, Kowalewski 2017.

${ }^{3}$ Mówimy tu ogólniej o materiałach (a nie publikacjach), mając na względzie ich różnorodność gatunkową (obejmującą nie tylko podręczniki, ale i tablice gramatyczne oraz dostępne w internecie filmy z wykładami o języku i o nauczaniu języka, kursy, ćwiczenia oraz gry online).

${ }^{4}$ Wskaźnikiem komunikacyjnego podejścia do gramatyki są nie tylko podręczniki kursowe, ale i innowacyjne zbiory zadań. Na szczególną uwagę zasługują wydane przed laty publikacje Teresy Pelc (1997) oraz Jolanty Lechowicz i Joanny Podsiadły (2001). Grażyna Zarzycka, podkreślając ich wartość, stwierdza, że: „można obie prace uznać za przełomowe w polskiej glottodydaktyce: po raz pierwszy tak mocno zintegrowano sferę gramatyki i komunikacji.” (Zarzycka 2003: 128). 
Drugim hasłem (pojawiającym się w kontekście nauczania języka polskiego studentów ze Wschodu) jest zwalczanie interferencji gramatycznych. W związku z tym, że wschodni Słowianie, którzy używają języka polskiego, wykazują się dużą sprawnością komunikacyjną, a zarazem wpadają w koleiny licznych interferencji, niezbędną rzeczą staje się uwrażliwianie odbiorców na różnice pomiędzy ich pierwszym językiem słowiańskim a nauczaną polszczyzną oraz wykonywanie ćwiczeń służących utrwalaniu właśnie tych form, które stają się częstą ofiarą transferu negatywnego (zob. m.in. Przechodzka 1993, Karczmarczuk, Przechodzka 1995, Skalska, Skalski 1995, Krawczuk 2006, 2008, 2015, Kowalewska 2014, Maliszewski 2014, 2019a, Izdebska-Długosz 2017, 2021a, 2021b, Kowalewski 2019).

Trzecim hasłem, którym można zwięźle ująć współczesne podejścia do nauczania gramatyki, jest wyrażenie gramatyka z kulturą. Stanowi ono intertekstualne nawiązanie do tytułu zbioru zadań poświęconego fleksji (Maliszewski 2020), a dzięki swojej wieloznaczności (czy ogólnikowości) może być używane w dość szerokim kontekście. W poniższym artykule omówimy trzy znaczenia „gramatyki z kulturą", ilustrując je wybranymi ćwiczeniami, które dobrze reprezentują współczesne ścieżki nauczania gramatyki.

\section{Z KULTURĄ, CZYLI PRZEJRZYŚCIE I ATRAKCYJNIE}

Pierwsze znaczenie wyrażenia „z kulturą" odnosi się do samego sposobu nauczania języka. Na wzór znanej zasady lekarskiej: Primum non nocere można tu ułożyć maksymę: Primum non deprimere (czyli nie deprymować, nie zniechęcać, nie zamęczać odbiorców nadmiarem reguł i zadań, dbając o dobrą atmosferę na lekcjach, atrakcyjność materiałów, ich przemyślany układ oraz odpowiednio zaplanowany czas).

Scenariusz zajęć językowych opiera się na klasycznym schemacie: prezentacja - praktyka - produkcja (Komorowska 1993, s. 117) ${ }^{5}$ i zwłaszcza ów pierwszy etap jest istotny, wprowadzając w temat lekcji oraz wyznaczając jej dalszy przebieg. Choć sam termin prezentacja - w odróżnieniu od dwóch pozostałych - konotuje pasywną postawę uczącego się (jako widza czy słuchacza), to jednak należy mieć na względzie, że nowe struktury gramatyczne są demonstrowane w ćwiczeniach (działaniach), a studenci są nakłaniani do wręcz nieustannej aktywności. Ważna jest tu zatem dbałość o wizualną oraz tematyczną atrakcyjność ćwiczeń, które

${ }^{5}$ Formułę tego schematu można nieco modyfikować i ukonkretniać. W związku z tym, że mianem prezentacji określa się zarówno wprowadzanie nauczanych struktur, jak i objaśnianie reguł, warto zawęzić zakres znaczeniowy tego terminu, rozróżniając fazę prezentacji (demonstrowania nauczanych struktur w początkowych ćwiczeniach) oraz fazę informacji (objaśniania reguł tworzenia danych form i wyszczególniania kontekstów ich użycia). 
- kierując uwagę na wprowadzane zagadnienia - powinny intrygować i rozbudzać chęć pracy z tekstem. Należy też pamiętać, że słuchane bądź czytane wypowiedzi, które są podstawą wykonywanych zadań, mają służyć nie tylko przedstawieniu nowych struktur, ale i powtarzaniu wprowadzonych już konstrukcji.

Jako przykład prezentacji nowego zagadnienia przywołajmy ćwiczenie z podręcznika Hurra!!! Po polsku, który od lat stanowi wzorzec nauczania gramatyki w podejściu komunikacyjnym (z rozbudowaną sferą realioznawczą):

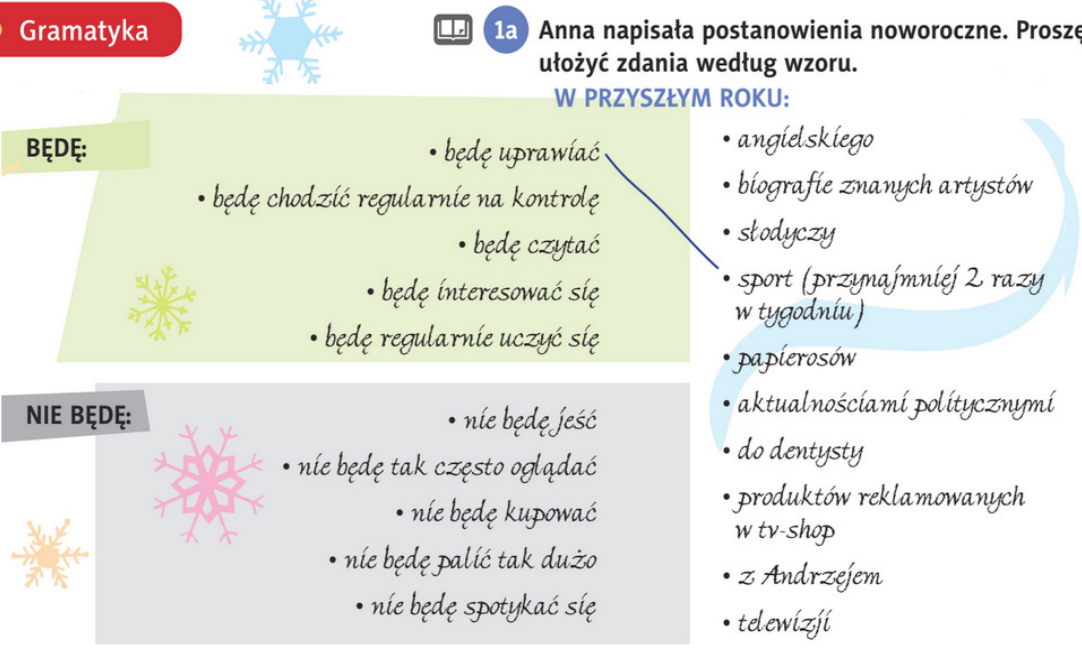

Źródło: Małolepsza, Szymkiewicz 2005, s. 92

Pierwszym (najłatwiej uchwytnym) walorem tego ćwiczenia jest jego atrakcyjność wizualna. Łączenie kolumn podlega ciekawemu rozplanowaniu, a zdania pisane kursywą na kolorowych polach (karteczkach) stwarzają wrażenie pisma odręcznego, dając poczucie obcowania z tekstem autentycznym. Interesujący jest również temat, który odwołuje się do sfery obyczajów (sporządzania listy postanowień noworocznych) oraz tego, co bliskie młodym odbiorcom (codzienne życie studentów i ich problemy). Ważne jest także to, że eksponowaniu nowej struktury (czasownika będę w połączeniach z bezokolicznikiem) towarzyszy utrwalanie urozmaiconego słownictwa oraz uprzednio wprowadzonych zagadnień fleksyjnych i składniowych. (Przypominane są końcówki narzędnika, biernika, dopełniacza rzeczowników oraz przymiotników 1. poj. i 1. mn.; prezentowane są czasowniki o zróżnicowanej rekcji, a ponadto powtarzana jest zasada zamiany biernika na dopełniacz w zdaniach przeczących).

Można więc podsumować, że powyższe ćwiczenie stanowi wręcz modelowy przykład wprowadzania nowych struktur gramatycznych, odznaczając się trzema istotnymi walorami, do których należy atrakcyjność formy graficznej, interesujący temat (bliski odbiorcom) oraz dbałość o to, by prezentacja nowych form szła $\mathrm{w}$ parze $\mathrm{z}$ utrwalaniem licznych zagadnień z poprzednich lekcji. 
W Gramatyce z kultura przedstawianiu struktur gramatycznych często służą ćwiczenia, które polegają na łączeniu popularnych sformułowań z odpowiednimi obrazkami (co ma na celu przedstawienie końcówek fleksyjnych, ukazywanie kontekstów ich użycia oraz sprawdzanie znajomości słownictwa). Wykorzystywaniu podlegają tu również pytania quizowe, dzięki którym można jeszcze wprowadzić element gry i rywalizacji. Na przykład przy demonstrowaniu form celownika użyciu podlega zwrot życzyć czegoś komuś, którego sposób wykorzystywania dobrze też służy przypomnieniu końcówek dopełniacza oraz sprawdzaniu kompetencji leksykalnej:

(1) Komu składamy te życzenia? Odpowiedz na pytania.

0. Powodzenia na egzaminie życzymy
a) studentowi.
b) wykładowcy.
c) nauczycielowi.

1. Przyjemnej podróży życzymy

a) klientowi.

b) pasażerowi.

c) taksówkarzowi.

2. Miłej lektury życzymy
a) widzowi.
b) słuchaczowi.
c) czytelnikowi.

3. Taaaakiej ryby życzymy
a) pływakowi.
b) marynarzowi.
c) wędkarzowi.

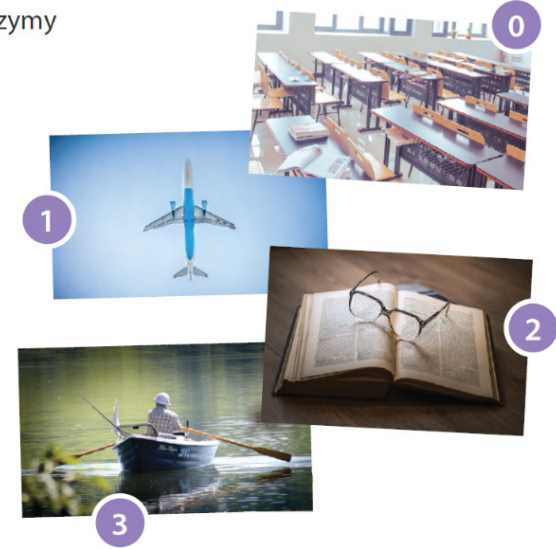

Źródło: Maliszewski 2020, s. 52

Zwieńczeniem fazy prezentacji jest odkrywanie bądź objaśnianie reguł gramatycznych i także na tym etapie warto zadbać o aktywność uczących się. Zamiast ograniczać się do podawania listy przykładowych form oraz wyjątków, dobrze jest skłonić odbiorców do samodzielnego uzupełniania tabelki zgodnie z podawanymi wskazówkami:

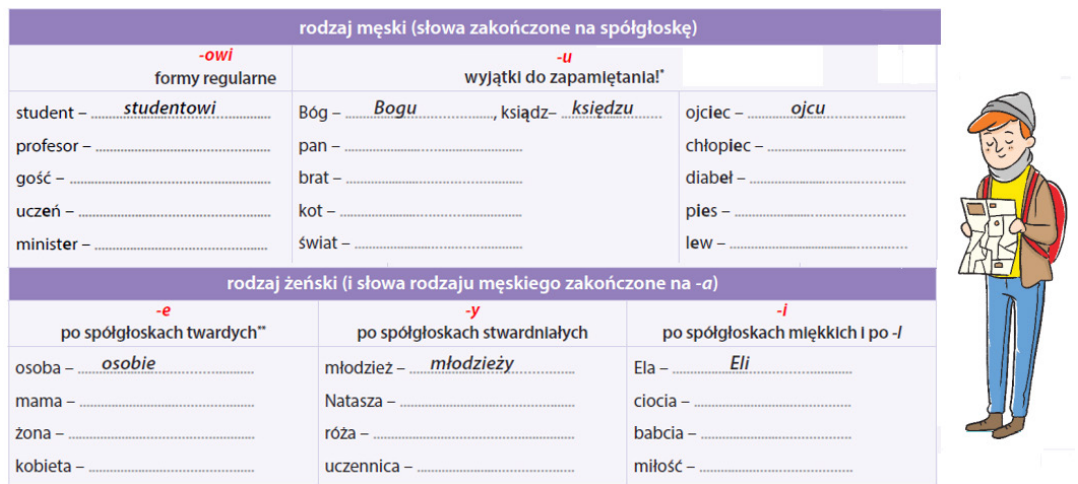

Źródło: Maliszewski 2020, s. 54 
Dzięki temu prostemu zabiegowi można silniej angażować uwagę uczących się, a ponadto dawać im poczucie przejrzystości reguł. W wypadku problemów napotykanych w kolejnych fazach lekcji uczący się powracają do samodzielnie wypełnionej tabelki, traktując ją jako swoistą „mapkę”, która ułatwia orientację w świecie gramatyki. Podstawowe pytanie, które jest zadawane w razie trudności z doborem właściwej końcówki fleksyjnej, brzmi: Gdzie jesteśmy?, a zadaniem odpowiadającego staje się wskazanie wiersza oraz kolumny, w której mieści się przekształcany leksem (co wymaga rozpoznania jego rodzaju i ponownego zwrócenia uwagi na zasady dystrybucji końcówek fleksyjnych).

Przy kolejnych etapach lekcji (praktyce i produkcji) ważna jest zasada stopniowania trudności - poczynając od krótkich ćwiczeń i podobnych transformacji, po dłuższe wypowiedzi o bardziej zróżnicowanej leksyce. Istotne jest również bogactwo bodźców, przekazów oraz typów zadań, czyli dbałość o to, by wielokrotne powtarzanie i utrwalanie materiału nie oznaczało jego monotonii (zob. Komorowska 1993, s. 126). Szczególnie dużo możliwości stwarza faza produkcji, podczas której studenci mogą się wcielać w różne role, dając wyraz swojej kreatywności oraz wchodząc w interakcje, które służą nie tylko rozwojowi kompetencji komunikacyjnej, ale i integracji grupy.

\section{Z KULTURĄ, CZYLI PROPAGOWANIEM POŻĄDANYCH ZACHOWAŃ}

Nauce języka już od pierwszych lekcji towarzyszy wdrażanie zasad etykiety (zaczynamy wszakże od powitań, pożegnań i sposobów zwracania się do odbiorcy). Przy wprowadzaniu form fleksyjnych czy składniowych można więc odwoływać się do znanych wypowiedzi grzecznościowych (np. popularne formy dziękuję, proszę, przepraszam stanowią dobry wstęp do zaprezentowania trzech koniugacji), a także nauczać kolejnych sformułowań, które ułatwiają nawiązywanie i podtrzymywanie dobrych relacji. Na przykład przy ćwiczeniu koniugacji warto wprowadzać wypowiedzi typu: Serdecznie gratuluję! Cieszę się, że cię widzę! Przepraszam, czy nie przeszkadzam?, Świetnie wygladasz!, Podoba mi się twój sweter!, Podobaja mi się twoje okulary!, co służy nie tylko utrwalaniu form czasowników, ale i propagowaniu pożądanych zachowań językowych.

Ćwiczenia poświęcone fleksji imiennej też często idą w parze z nauczaniem grzeczności. Końcówki dopełniacza i celownika można powtarzać przy składaniu życzeń oraz gratulacji. Popularny biernik towarzyszy licznym aktom etykiety (przepraszamy kogoś za coś, prosimy kogoś o coś, zapraszamy kogoś na coś, wznosimy toasty za kogoś lub za coś). Narzędnik staje się przydatny przy wyrażaniu komplementów (jesteś świetnym kolega / świetna koleżanka), a wołacz jest nieodzowny przy budowaniu zwrotów do adresata. 
Poszczególne formy fleksyjne podlegają utrwaleniu także przy okazji rozmów o zasadach savoir vivre’u - np. ćwiczeniu dopełniacza dobrze służy dyskusja o tym, czego nie wypada (nie można, nie należy, nie wolno) robić przy stole, przy celowniku omówieniu podlegają zasady pierwszeństwa - kto komu się kłania (przedstawia), kto komu podaje rękę, przy bierniku można zadawać pytania, kogo należy powitać w pierwszej kolejności, w co trzeba się ubrać na poszczególne okazje (egzamin, randkę), co wypada kupić, gdy idziemy w gości itp.

Propagowanie pożądanych zachowań nie ogranicza się jednak do samej etykiety i okazywania szacunku innym rozmówcom. We współczesnych materiałach do nauki języka widoczny staje się nacisk na edukację zdrowotną, ekologiczną czy obywatelską. Także przy okazji ćwiczeń na fleksję imienną czy werbalną warto uwrażliwiać uczących się na istotne problemy społeczne, upowszechniając właściwe wzorce postępowań (ów wychowawczy aspekt ćwiczeń jest pożądany zwłaszcza w pracy z młodzieżą, choć oczywiście należy tu unikać nadmiernego moralizatorstwa, dbając o angażowanie uwagi odbiorców i stosując elementy zabawy).

\section{Z KULTURĄ, CZYLI Z ELEMENTAMI WIEDZY O POLSCE}

Zagadnienia tematyczne wyszczególnione w „Europejskim systemie opisu kształcenia językowego" wprowadzają w rozbudowaną sferę realioznawczą ${ }^{6}$, a podejmowanie wyróżnionych tematów służy nie tylko rozwojowi kompetencji gramatycznej, leksykalnej i komunikacyjnej, ale też dostarcza okazji, by przekazywać liczne informacje o kulturze dnia codziennego, ważnych obyczajach, znanych wydarzeniach, atrakcyjnych miejscach, dziełach sztuki, sławnych osobach ${ }^{7}$.

Coraz większy nacisk na łączenie nauki polskiego z przekazywaniem wiedzy o Polsce i jej kulturze uobecnia się w trojaki sposób. Pierwszym wskaźnikiem jest rosnąca liczba publikacji na temat nauczania kultury na lekcjach języka polskiego jako obcego ${ }^{8}$. Drugim świadectwem jest coraz bogatszy zasób podręczników, których autorzy - w ćwiczeniach służących rozwijaniu sprawności

${ }^{6}$ Klasyfikacja zagadnień tematycznych obejmuje ogólnikowo zakreślone dziedziny: 1. Dane osobowe, 2. Dom, mieszkanie, otoczenie, 3. Życie codzienne, 4. Czas wolny, rozrywka, 5. Podróże, 6. Stosunki międzyludzkie, 7. Zdrowie i higiena, 8. Edukacja, 9. Zakupy, 10. Żywność i napoje, 11. Usługi, 12. Miejsca, 13. Język, 14. Pogoda, a wyróżnione tu kategorie podlegają dalszej specyfikacji (wyodrębnione zostają podtematy i pojęcia szczegółowe) (ESOKJ 2003, s. 57-58).

${ }^{7}$ Już same okładki podręczników do nauki języka polskiego bywają zapowiedzią rozbudowanego komponentu kulturowego (np. na okładce Hurra!!! Po polsku widnieje rysunek Pałacu Kultury i Sukiennic, a podręczniki z serii Krok po kroku przyciągają wzrok zdjęciami krakowskiego rynku, pozwalając oczekiwać bogato ilustrowanych lekcji, które przybliżają polskie realia i promują polską kulturę).

${ }^{8}$ Zob. m.in. prace zamieszczone w tomie pod redakcją Władysława Miodunki (2004) oraz monografie: Burzyńska 2002, Garncarek 2006, Gębal 2010, Kowalewski 2011, Nawracka 2020. 
językowych - wykazują dbałość o to, by dostarczać licznych informacji na temat Polski ${ }^{9}$. Trzecim przejawem wagi przywiązywanej do promocji polskiej kultury w materiałach do nauki języka jest coraz ściślejsza integracja obu zagadnień, czego dobrym przykładem jest m.in. podręcznik Jestem stąd, zbiór plansz: O Polsce po polsku, a także podręcznik Po polsku po Polsce oraz związana z nim platforma internetowa www.popolskupopolsce.edu.pl.

Co zrozumiałe, im wyższy poziom nauczania języka, tym bardziej rozbudowany staje się komponent kulturowy. Na pierwszych lekcjach prezentowane są mapki Polski z nazwami miast, co służy ćwiczeniu fonetyki (zadanie odbiorców ogranicza się do odczytywania bądź powtarzania danych nazw) oraz utrwalaniu różnych rodzajów gramatycznych (uczący się mają pogrupować odczytywane toponimy wedle ich przynależności rodzajowej) (Małolepsza, Szymkiewicz 2005, s. 7; Machowska 2010, s. 31; Maliszewski 2020, s. 11). W kolejnych lekcjach nazwy polskich miast występują już w przypadkach zależnych i związanych z nimi konstrukcjach, a w ćwiczeniach gramatyczno-leksykalnych pojawia się coraz większy zasób informacji. Przy utrwalaniu form narzędnika studenci wskazują, nad jaką rzeką leżą dane miasta, a przy zadaniu na łączenie kolumn (bądź dopasowywanie tekstu do obrazka) mówią, z czym się kojarzą (Kraków - ze smokiem, Warszawa - z syrenką, Gdańsk - z morzem). Przy wprowadzaniu miejscownika studenci określają położenie poszczególnych miast za pomocą wyrażeń: na pótnocy / potudniu / wschodzie / zachodzie, a przy zadaniu na łączenie kolumn mówią, gdzie znajdują się prezentowane zabytki (pomnik smoka - w Krakowie, pomnik syrenki - w Warszawie, pomnik Neptuna - w Gdańsku). Wraz z przekazywaniem kolejnych informacji na temat polskich miast pojawiają się dłuższe teksty na ich temat i coraz wyraźniejsza staje się promocja polskiej kultury. Osnową bardziej rozbudowanych ćwiczeń gramatycznych stają się na przykład maile, których nadawcy piszą o tym, gdzie byli, co służy nie tylko utrwalaniu wybranych form fleksyjnych, ale i promowaniu poszczególnych miejsc oraz związanych z nimi atrakcji turystycznych (ukazywanych również na fotografiach, które towarzyszą danym tekstom - zob. Maliszewski 2020, s. 106-107).

Podobnie i sylwetki znanych postaci warto już wprowadzać przy okazji najprostszych ćwiczeń gramatycznych, by następnie sięgać po coraz bardziej rozbudowane teksty, które wyjaśniają, kim są poszczególne postaci. Ten sam

\footnotetext{
${ }^{9}$ Można tu wymienić takie podręczniki kursowe, jak: Hurra!!! Po polsku; Polski krok po kroku; Start; Polski jest cool; Polski? Chcę i mogę!; Polski mniej obcy; Polski bez tajemnic; Jestem stad; Z polskim w świat; Język polski bez granic. Nacisk na promowanie polskiej kultury i przekazywanie wiedzy o Polsce uobecnia się również w materiałach dodatkowych - np. we wspomnianym już zbiorze ćwiczeń Teraz polski tematem rozmów z użyciem czasu przeszłego są wydarzenia z życia znanych osobistości (Curie-Skłodowska, Sienkiewicz, Chopin), a w Ten, ta, to osnową ćwiczeń służących rozwojowi kompetencji gramatycznej są m.in. teksty dotyczące polskich noblistów, co stanowi dodatkową wartość danych publikacji (Zarzycka 2003, s. 128).
} 
zestaw materiałów wizualnych może być wykorzystywany przy podejmowaniu kolejnych tematów. Na przykład okładka filmu Bogowie z Tomaszem Kotem w garniturze i białym fartuchu staje się przydatna już od pierwszych lekcji, pojawiając się przy utrwalaniu form mianownika (To jest aktor. To jest lekarz. On jest młody, przystojny, elegancki), końcówek narzędnika (On jest aktorem. On jest lekarzem.), biernika (Widzimy lekarza. On ma na sobie garnitur i fartuch.) czy miejscownika (Ten film jest o lekarzu.). Studenci nie muszą tu jeszcze widzieć, kim jest osoba widoczna na zdjęciu (będącym po prostu jednym z wielu bodźców wizualnych), ale wraz z rozwojem procesu nauczania, przybliżaniu podlega jej sylwetka. Przy ćwiczeniu form mianownika rodzaju męskoosobowego okładka filmu Bogowie pojawia się ponownie, ale tym razem towarzyszy już dłuższemu tekstowi, który służy przedstawieniu Zbigniewa Religi oraz zarekomendowaniu ważnego dzieła polskiej kinematografii:

\section{Film „Bogowie"}

Zbigniew Religa był lekarzem i chirurgiem z wielką pasją. Nie interesował się tym, kogo operuje. Nieważne, czy byli to wielcy artyści (artysta) ${ }^{0}$, znani $\left(\right.$ polityk) ${ }^{1}$, wspaniali (sportowiec) $)^{2}$ czy zwykli $\left(\right.$ człowiek) ${ }^{3}$.

Wszyscy (pacjent) ${ }^{4}$ byli tak samo ważni, a profesor Religa robił wszystko, żeby ratować ich życie. To właśnie on jako pierwszy w Polsce wykonał udany przeszczep serca. O tym sukcesie mówili wtedy wszyscy polscy (chirurg) $^{5}$ i

(dziennikarz) ${ }^{6}$, a dzisiaj mówi o nim film „Bogowie”.

(Twórca) ${ }^{7}$ filmu wykonali naprawdę dobrą pracę. Historia jest ciekawa, a akcja - bardzo dynamiczna. Wszyscy $(\text { aktor })^{8}$ perfekcyjnie grają swoje role. Tomasz Kot wygląda jak prawdziwy profesor Religa, a jego też są świetni jako $(\text { lekarz })^{10}$.

Nic dziwnego, że widzowie oraz pozytywnie oceniają film, a rodzina i

Zbigniewa Religi dodają, że reżyser dobrze pokazał charakter legendarnego profesora.
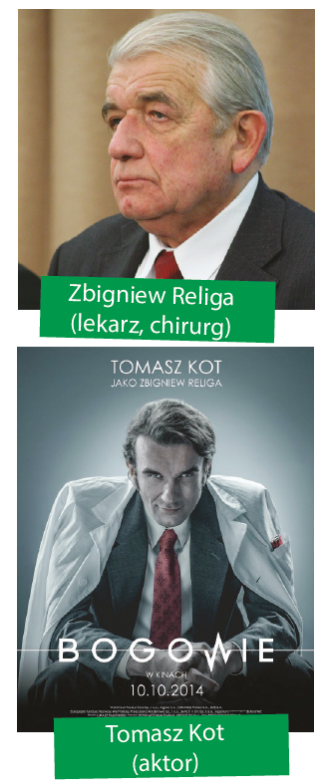

Źródło: Maliszewski 2020, s. 30

Pokazując te same obrazy w różnych kontekstach, utrwalamy ich znajomość, a zarazem sprawiamy, że uczący się doświadczają efektów nauczania. Powtarzane bodźce wizualne stają się źródłem rozbudowywanych wypowiedzi, gdyż odbiorcy potrafią już coraz więcej rzeczy nazwać, dostrzec i wyjaśnić, manifestując swoją znajomość języka oraz kultury. (Podobnie i fotografie zabytków mogą początkowo służyć krótkim opisom, by następnie stać się tematem dłuższych wypowiedzi - bardziej szczegółowych prezentacji, opowiadanych legend czy historii).

Odwołania do poszczególnych osób, miejsc czy zabytków różnią się więc swoim charakterem - poczynając od drobnych nawiązań oraz „inkrustowania” 
układanych ćwiczeń nazwami własnymi, które zakorzeniają dany tekst w polskich realiach, po rozbudowane ćwiczenia, których osnową są dłuższe artykuły poświęcone atrakcjom turystycznym, znanym postaciom czy dziełom sztuki. Częstemu wykorzystywaniu podlegają także teksty piosenek (rzadziej zaś utwory poetyckie czy prozatorskie), które służą nauczaniu wybranych zagadnień gramatyczno-leksykalnych oraz popularyzowaniu polskiej muzyki i literatury ${ }^{10}$.

Coraz większa liczba podręczników, które kładą nacisk na promocję polskiej kultury, w sposób nieunikniony prowadzi do powtarzalności prezentowanych osób, miejsc, zabytków, tradycji (w niejednym podręczniku odnajdziemy wszakże odwołania do polskich noblistów, zdjęcia popularnych zabytków czy teksty na temat Wielkanocy czy Bożego Narodzenia), co sprzyja utrwalaniu podejmowanych zagadnień i budowaniu pewnego kanonu kulturowego. $Z$ drugiej strony rosnąca liczba materiałów do nauczania języka prowadzi też do coraz większej różnorodności przekazywanych treści kulturowych, co również ma swoje zalety (rozszerzeniu podlega bowiem zasób przedstawianych postaci i zabytków). Tematycznej różnorodności sprzyja fakt, że autorzy podręczników pracują w różnych ośrodkach akademickich i promują lokalną kulturę (w poszczególnych ćwiczeniach bądź całych zbiorach zadań) ${ }^{11}$.

\section{CZTERY FILARY NAUCZANIA GRAMATYKI}

Podsumowując uwagi na temat nauczania gramatyki we współczesnej glottodydaktyce, można tu wyodrębnić cztery filary, na których opiera się dany proces.

Pierwszym filarem jest oczywiście wiedza nauczyciela, który powinien mieć opanowaną naukę o języku i orientować się w jego tendencjach rozwojowych. Równie istotna jest tu wiedza glottodydaktyczna, czyli znajomość metodyki, a w pracy z grupami słowiańskimi - także świadomość typowych interferencji (można wtedy dobierać bądź układać takie zadania, których celem jest utrwalanie form, które często padają ofiarą transferu negatywnego - zob. Dąbrowska, Dobesz, Pasieka 2010, s. 59-75). Pożądana jest tu również bogata

${ }^{10} \mathrm{O}$ sposobach wykorzystywania piosenek i tekstów literackich w procesie glottodydaktycznym - zob. m.in. Siek-Piskozub, Wach 2006, Łaszkiewicz 2010, Czerkies 2012, Próchniak 2012, Kaźmierczak 2019.

${ }^{11} \mathrm{~Np} . \mathrm{w}$ „łódzkim” Ten, ta, to pojawia się mapka przedstawiająca centrum Łodzi (Lechowicz, Podsiadły 2001, s. 28), w wydanym przez Uniwersytet Śląski podręczniku Polski mniej obcy osnową jednego z ćwiczeń jest legenda o Cieszynie (Madeja, Morcinek 2007, s. 19-20), a w wydanym przez UMCS $Z$ polskim $w$ świat ilustracją miasteczka akademickiego jest fragment mapki Lublina (Ciesielska-Musameh, Guziuk-Świca, Przechodzka 2016, s. 60). Promowaniu kultury lokalnej poprzez nauczanie i testowanie języka polskiego służą też osobne publikacje - m.in. $Z$ Wrocławiem w tle, Wokót Lublina, Spacerkiem po Łodzi i okolicy. 
wiedza kulturoznawcza, dzięki której nauczyciel może pozyskiwać uwagę odbiorców, nawiązywać lepszy kontakt z grupą i dopełniać treść rozmów licznymi ciekawostkami.

Drugim filarem nauczania gramatyki jest pragmatyka językowa. W centrum procesu glottodydaktycznego znajduje się bowiem odbiorca, który chciałby efektywnie się posługiwać językiem polskim (a nie słuchać wykładów na jego temat). Zagadnienia gramatyczne należy więc odpowiednio selekcjonować, porządkować i wyjaśniać w przystępny sposób (a dużą rolę odgrywa tu infografika) bądź - przy zastosowaniu metody indukcyjnej - sprawiać, by to uczący się odkrywał reguły na podstawie wykonywanych ćwiczeń. Ważne jest również, by rozwój kompetencji gramatycznej nie był traktowany jako cel, ale jako środek realizowania poszczególnych intencji komunikacyjnych (np. dzięki znajomości dopełniacza możemy wyrazić negację, powiedzieć dokąd idziemy, poprosić o określoną ilość czegoś, złożyć życzenia, napisać pozdrowienia itd.). Przy nauczaniu języka ważna jest więc odpowiedź na trzy kluczowe pytania: czego uczyć (selekcja struktur), jak uczyć (dobór metod, technik, ćwiczeń) i po co uczyć (nacisk na użyteczność wprowadzanych konstrukcji) ${ }^{12}$.

Trzecim filarem nauczania gramatyki jest atrakcyjność ćwiczeń gramatycznych oraz ich różnorodność. Ważne, by szukać takich wątków, które są ciekawe dla odbiorców. Jak bowiem podkreśla Hanna Komorowska: „Dobór materiału, jeśli ma na celu skupienie uwagi, musi odpowiadać zainteresowaniom uczniów. Znając te zainteresowania, można odpowiednio aranżować sytuacje tak, by były przez uczniów traktowane jako zajmujące. Zasada ta w szczególności nadaje się do nauczania materiału gramatycznego." (Komorowska 1993, s. 78). Warto przy tym pozostawiać uczącym się pewien margines swobody w wybieraniu tematów i sytuacji komunikacyjnych (Komorowska 1993, s. 78). Na przykład przy ćwiczeniu form czasu przeszłego uczniowie mogą wcielać się w dowolne postaci i pisząc kartkę z pamiętnika (Co dziś robiłem? Co dziś robiłam?), starają się dostarczyć takich informacji, które umożliwią słuchaczom odgadnięcie, czyj to pamiętnik. Dzięki temu uczący się angażują się w proces tworzenia wypowiedzi oraz uważniej słuchają innych osób, a nauczyciel zyskuje przy tym informację o zainteresowaniach i kompetencji kulturowej poszczególnych nadawców, którzy wcielają się w wybrane przez siebie postaci (piosenkarzy, aktorów, sportowców, polityków, bohaterów filmowych czy literackich).

Czwartym filarem kształcenia językowego jest przekazywanie wiedzy o Polsce - nauczanie gramatyki stwarza bowiem znakomitą okazję, by przybliżać uczącym się sylwetki sławnych osób, ważne wydarzenia, najcenniejsze zabytki, popularne zwyczaje. Na przykład przy nauczaniu miejscownika można

${ }^{12}$ Więcej na temat metod i technik nauczania gramatyki: Komorowska 1993, s. 117-127, Seretny, Lipińska 2005, s. 111-133, Dąbrowska, Dobesz, Pasieka 2010, s. 97-104, Jasińska 2016, Gębal, Miodunka 2020, s. 228-250. 
prezentować tytuły filmów biograficznych, by w ćwiczeniach gramatycznych informować, o kim (o czym) one są, zachęcając przy tym do ich obejrzenia. Uczący się mogą też dowiadywać się o atrakcjach turystycznych, które znajdują się w poszczególnych miastach Polski, a następnie losować kartki z ich fotografiami, dając wyraz nie tylko opanowaniu form miejscownika (Gdzie jestem?), ale i znajomości przedstawianych zabytków ${ }^{13}$.

Zestaw podobnych materiałów można wykorzystywać przy wprowadzaniu kolejnych zagadnień gramatycznych. Na przykład pocztówki z różnymi miejscami stają się przydatne przy ćwiczeniu różnych czasów. Na podstawie losowanych fotografii studenci piszą pozdrowienia, opowiadając o tym, co robią w danym miejscu albo piszą mail o tym, dokąd pojechali i jak spędzali tam czas bądź mówią o swoich planach wakacyjnych. Losowane pocztówki mogą też służyć sprawdzaniu znajomości trybu przypuszczającego - np. Gdybym byt(a) na Mazurach, to... oraz form trybu rozkazującego - nadawcy udzielają tu wskazówek, co wziąć ze sobą, co robić, a czego nie robić, a odbiorcy starają się odgadnąć, jakiego miejsca dotyczą dane porady. Takie ćwiczenia pozwalają rozwijać kompetencję językową, a zarazem utrwalać zasób informacji na temat polskich atrakcji turystycznych.

Cztery filary nauczania gramatyki można więc krótko przedstawić w następujący sposób:

1. Wiedza nauczyciela

a) wiedza językoznawcza (znajomość terminów, reguł, tendencji rozwojowych)

b) wiedza glottodydaktyczna (znajomość metodyki, wiedza na temat interferencji)

c) kompetencja kulturowa (znajomość historii, dzieł sztuki, realiów)

2. Pragmatyka językowa

a) nastawienie na cele nauczania i jego efektywność (przy nauczaniu Słowian - dążenia do zwalczania interferencji)

b) ograniczanie teorii (komentarzy metajęzykowych)

c) nacisk na ćwiczenia komunikacyjne, praktykę językową

3. Atrakcyjność éwiczeń

a) „atrakcyjność codzienności”, sceny z życia wzięte, podejmowanie tematów bliskich odbiorcom

b) różnorodność bodźców, typów zadań, sytuacji komunikacyjnych

c) ludyczność (elementy humoru, zabawy, rywalizacji)

${ }^{13}$ Oczywiście, tego typu materiały wizualne nie muszą się ograniczać do polskiej kultury. By angażować uwagę uczących się i wzbogacać zasób słownictwa, warto wykorzystywać fotografie przeróżnych miast, dzieląc je np. na trzy kategorie: Polska, Europa, świat i pozwalając wybrać uczącym się zestaw, z którego losują zdjęcie będące przedmiotem wypowiedzi. 


\section{Promocja kultury}

a) rozbudowywanie sfery realioznawczej (której i tak nie sposób uniknąć)

b) nauczanie etykiety i promowanie pożądanych społecznie zachowań

c) przekazywanie wiedzy o Polsce (i świecie), porównywanie różnych kultur, zachęcanie do dalszej aktywności poznawczej

Na zakończenie warto wspomnieć, że - jak świadczą badania ankietowe przeprowadzane w CJKP UMCS - sami uczący się dostrzegają (i doceniają) powyższe wartości. W ankiecie przeprowadzonej w 2017 roku (na zakończenie miesięcznego kursu przygotowawczego dla Ukraińców zaczynających studia w Polsce) zadania gramatyczne często wymieniano wśród lubianych zadań, a wśród ich zalet podawano to, że były one ważne, przydatne i ciekawe (Maliszewski 2019, s. 52).

Istotne jest zatem to, by - w zależności od potrzeb oraz stopnia zaawansowania grupy - starannie dobierać przydatne struktury gramatyczne (które przy nauczaniu wschodnich Słowian padają ofiarą częstych interferencji), a zarazem dbać o atrakcyjny sposób ich nauczania, co nie tylko zwiększa efektywność procesu glottodydaktycznego, ale też pozostawia miłe wspomnienia z kursu językowego. Ważne też, by wykorzystywać naukę gramatyki do przybliżania polskich realiów, rozbudzania zainteresowania polską kulturą, przekazywania wiedzy na jej temat i zachęcania do dalszej aktywności poznawczej.

\section{BIBLIOGRAFIA}

Burzyńska A.B., 2002, Jakże rad bym się nauczyt polskiej mowy... O glottodydaktycznych aspektach relacji język a kultura w nauczaniu języka polskiego jako obcego, Wrocław.

Butcher A., Maliszewski B., Przechodzka G., Rzeszutko-Iwan M., Trębska-Kerntopf A., 2009, Wokót Lublina. Zadania testowe z języka polskiego dla obcokrajowców, Lublin.

Ciesielska-Musameh R., Guziuk-Świca B., Przechodzka G., 2016, Z polskim w świat. Podręcznik do nauki języka polskiego jako obcego, Lublin.

Czerkies T., 2012, Tekst literacki w nauczaniu języka obcego (z elementami pedagogiki dyskursywnej), Kraków.

Dąbrowska A., Burzyńska-Kamieniecka A., Dobesz U., Pasieka M., 2005, Z Wrocławiem w tle. Zadania testowe z języka polskiego dla cudzoziemców, Wrocław.

Dąbrowska A., Dobesz U., Pasieka M., 2010, Poradnik metodyczny dla nauczycieli języka polskiego jako obcego na Wschodzie, Warszawa.

Dembowska-Wosik I., Strzelecka A., Zawada A., 2011, Spacerkiem po Lodzi i okolicy. Teksty i ćwiczenia do nauki języka polskiego dla cudzoziemców, Łódź.

Europejski system opisu kształcenia językowego: uczenie się, nauczania, ocenianie (ESOKJ), 2003, Warszawa.

Foland-Kugler M., 2001, Uczymy polskiego na Wschodzie, Warszawa.

Garncarek P., 2006, Przestrzeń kulturowa w nauczaniu języka polskiego jako obcego, Warszawa.

Gębal P.E., 2010, Dydaktyka kultury polskiej w kształceniu językowym cudzoziemców. Podejście porównawcze, Kraków. 
Gębal P. E., Miodunka W. T., 2020, Dydaktyka i metodyka nauczania języka polskiego jako obcego $i$ drugiego, Warszawa.

Izdebska-Długosz D., 2016, Uczyć czy nie uczyć? Przemiany miejsca i roli gramatyki $w$ świetle metod nauczania języków obcych, „Acta Humana” 7, s. 93-103. http://dx.doi.org/10.17951/ ah.2016.7.93

Izdebska-Długosz D., 2017, Po polsku bez błędu. Zbiór ćwiczeń z gramatyki języka polskiego dla studentów ukraińskojęzycznych: A2-B2, Rzeszów.

Izdebska-Długosz D., 2021a, Błędy gramatyczne w polszczyźnie studentów ukraińskojęzycznych, Kraków.

Izdebska-Długosz D., 2021b, Polski dla nas. Deklinacja i sktadnia kontrastywnie dla Stowian wschodnich (A2-B2), Kraków.

Jasińska A., 2016, Jak objaśniać gramatykę uczacym się języka polskiego jako obcego, „Annales Universitatis Paedagogicae Cracoviensis. Studia Ad Didacticam Litterarum Polonarum Et Linguae Polonae Pertinentia" 7 (223), 67-78.

Jasińska A., Waliszko M., 2015, O Polsce po polsku. Plansze tematyczne do nauki języka polskiego jako obcego dla poziomu A1/A2, Berlin.

Język polski bez granic, Seria podręczników do nauki języka polskiego jako obcego dla szkót ukraińskich (klasy V-XI), http://www.wspolnotapolska.org.pl/bezgranic/index.php (dostęp: 01.08.2021).

Karczmarczuk B., Przechodzka G., 1995, Różnice strukturalne między językiem polskim i rosyjskim a kształcenie sprawności komunikacyjnej (wybrane zagadnienia), w: Kształcenie sprawności komunikacyjnej Polaków ze Wschodu, J. Mazur (red.), Lublin, s. 137-146.

Kaźmierczak P., 2019, Piosenka pomoże na wiele, czyli o alternatywnych sposobach ksztaltowania kompetencji gramatycznej, ,Acta Universitatis Lodziensis. Kształcenie Polonistyczne Cudzoziemców", t. 25, s. 137-148. https://doi.org/10.18778/0860-6587.25.12

Komorowska H., 1993, Podstawy metodyki nauczania języków obcych, Warszawa.

Kowalewska M., 2014, Co nas tączy... Teoria i zbiór ćwiczeń z gramatyki języka polskiego, Kraków.

Kowalewski J., 2011, Kultura polska jako obca?, Kraków.

Kowalewski J., 2013, Jak uczyć języka polskiego i kultury polskiej na Ukrainie, Kraków.

Kowalewski J., 2019, Gramatyka dla heretyka - nie tylko uczacych (się) języka polskiego na Ukrainie, Kraków.

Krawczuk A., 2006, Btędy gramatyczne studentów polonistyki lwowskiej spowodowane polsko-ukraińska interferencją, „Postscriptum”, nr 2 (52), s. 137-153.

Krawczuk A., 2008, Polska mowa - Ukraińcam, Lwiw.

Krawczuk A., 2015, Polska mowa. Gramatika z wprawami, Kyjiw.

Krawczuk A., Kowalewski J., 2017, Metodika wyktadania polskoj mowy, Kyjiw.

Krawczuk A., Kowalewski J., 2019, Jestem stad. Pidrucznik z polskoj mowy, Lwiw.

Lechowicz J., Podsiadły J., 2001, Ten, ta, to. Ćwiczenia nie tylko gramatyczne dla cudzoziemców, Łódź.

Łaszkiewicz M., 2010, Piosenka jest dobra na wszystko?, „Acta Universitatis Lodziensis. Kształcenie Polonistyczne Cudzoziemców", t. 17, s. 335-341.

Machowska J., 2010, Gramatyka? Dlaczego nie?! Ćwiczenia gramatyczne dla poziomu A1, Kraków.

Madeja A., Morcinek B., 2007, Polski mniej obcy Podręcznik do nauki języka polskiego dla średnio zaawansowanych, Katowice.

Maliszewski B., 2014, Per errata ad astra - zwalczanie interferencji gramatycznych $w$ procesie nauczania języka polskiego studentów ze Wschodu, w: Błą w literaturze, kulturze i językach narodów słowiańskich, M. Dziwisz i in. (red.), Lublin, s. 221-230.

Maliszewski B., 2019a, Ku absencji interferencji - sposoby utrwalania poprawnych form gramatycznych w nauczaniu języka polskiego młodzieży z Ukrainy, „Roczniki Humanistyczne”, t. LXVII, z. 10, s. 99-112. 
Maliszewski B., 2019b, Bariery i pomosty w sytuacjach komunikacyjnych na lekcji języka polskiego jako obcego, „Język a Edukacja”, t. 7, D. Lech-Kirstein, M. Makuchowska (red.), Opole, s. 49-59.

Maliszewski B., 2020, Gramatyka z kultura. Przez przypadki, K. Wójcik (oprac.), Lublin.

Małolepsza M., Szymkiewicz A., 2005, Hurra!!! Po polsku 1, Kraków.

Małyska A., Dembińska K., 2010, Start 1. Survival Polish, Warszawa.

Mazur J. (red.), 1992, 1993, 1994, 1995, 1996, tomy pokonferencyjne z serii: Ksztatcenie Polaków ze Wschodu, Lublin.

Miodunka W. (red.), 2004, Kultura w nauczaniu języka polskiego jako obcego. Stan obecny - programy nauczania - pomoce dydaktyczne, Kraków.

Nawracka M.J., 2020, Nauczanie języka polskiego jako obcego w perspektywie refleksyjnej i kulturowej, Kraków.

Pelc T., 1997, Teraz polski. Gry i ćwiczenia komunikacyjne. Podręcznik dla nauczycieli języka polskiego jako obcego, Łódź.

Piotrowska-Rola E., Porębska M., 2017, Polski jest cool, Lublin.

Prizel-Kania A., Bucko D., Sowa K., Majcher-Legawiec U., 2016, Po polsku po Polsce, Kraków.

Próchniak W., 2012, Klucz do wierszy. Poezja w nauczaniu języka polskiego jako obcego, Lublin.

Przechodzka G., 1993, Z problematyki interferencji językowej w nauczaniu języka polskiego Polaków ze Wschodu, w: Metodyka kształcenia językowego Polaków ze Wschodu, J. Mazur (red.), Lublin.

Sałęga-Bielowicz B., Gałat E., 2018, Język polski? Chcę i mogę, Kraków.

Seretny A., Lipińska E., 2005, ABC metodyki nauczania języka polskiego jako obcego, Kraków.

Siek-Piskozub T., Wach A., 2006, Muzyka i słowa. Rola piosenki w procesie przyswajania języka obcego, Poznań.

Skalska A., Skalski T., 1995, Pułapka komunikatywności, w: Kształcenie sprawności komunikacyjnej Polaków ze Wschodu, J. Mazur (red.), Lublin, s. 49-57.

Skorupa E., Lipińska E., 2010, Polski bez tajemnic. Język polski dla studentów niemieckojęzycznych, Kraków.

Stempek I., Stelmach A., 2012, Polski. Krok po kroku. Kraków.

Zarzycka G., 2003, Gramatyka a podejście komunikacyjne w nauczaniu języka polskiego jako obcego, „Przegląd Polonijny”, z. 4, s. 122-128.

\section{Barttomiej Maliszewski}

\section{GRAMMAR WITH CULTURE - ON CONTEMPORARY APPROACHES TO TEACHING GRAMMAR}

Keywords: teaching Polish as a foreign language, grammar, flection, culture

Summary. When developing grammar proficiency, language pragmatics (effectiveness of communication) are the primary focus, and the knowledge of grammar is perceived as a means of utterance creation, serving to implement specific intentions of the sender. The subject of this article is the apparent focus on the "attractiveness" of the exercises and the connection of grammatical issues with Polish culture knowledge transfer. The expression "Grammar with culture" through its ambiguity allows the characterization of the contemporary ways of shaping grammatical competence in teaching Polish as a foreign language. The words "with culture" mean: a polite (attractive, transparent) promotion of the desired behaviour and transfer of knowledge about the Polish culture. 
